Didaktik : J urnal Pendidikan Guru Sekolah Dasar, ISSN : 2477-5673

Sekolah Tinggi Keguruan dan IImu Pendidikan Subang

Volume I Nomor 1, Desember 2015

\title{
ANALISIS PROBLEMATIKA PENDIDIKAN SEKOLAH DASAR MENUJU PARADIGMA PENDIDIKAN BARU MELALUI PENINGKATAN PROFESIONALISME GURU SEKOLAH DASAR
}

\author{
Suhendra Permadi, M.Pd \\ STKIP Subang \\ permadi.suhendra@gmail.com
}

\begin{abstract}
ABSTRAK
Penulisan ini bertujuan untuk mengetahui keefektifan profesionalitas guru sekolah dasar dalam menyelesaikan problematika pendidikan sekolah dasar (SD) saat ini menuju ke arah paradigma pendidikan baru sesuai dengan yang dicita-citakan pendidikan pancasila. Era globalisasi menuntut kesiapan sumber daya manusia (SDM) yang memiliki keunggulan kompetitif dan komparatif. Upaya menyiapkan sumber daya manusia yang unggul salah satunya dapat dicapai melalui pendidikan. Penulisan ini juga dilatarbelakangi oleh adanya permasalahan yang terkait dengan masih rendahnya mutu pendidikan dalam skala nasional, yang salah satunya diakibatkan lemahnya kemampuan guru dalam melaksanakan tugas-tugas profesionalnya. Tantangan dan tuntutan terhadap profesionalitas guru di masa mendatang akan semakin berat dengan pesatnya perkembangan masyarakat, ilmu pengetahuan, dan teknologi serta adanya persaingan di era globalisasi. Untuk menjamin adanya peningkatan kualitas pendidikan di masa mendatang, diperlukan upaya-upaya dalam mengoptimalkan proses pembinaan dan pengembangan profesi guru sekolah dasar melalui pendidikan dan pelatihan yang berkesinambungan dan komprehensif dengan akses yang lebih luas dan menjangkau seluruh guru secara nasional.
\end{abstract}

Kata Kunci : problematika pendidikan, profesionalisme guru, paradigma baru, sekolah dasar.

\section{ABSTRACT}

This research aims to determine the effectiveness of a primary school teacher professionalism in solving the problems of primary school (SD) is currently heading towards a new paradigm of education in accordance with the aspired Pancasila education. The era of globalization requires the readiness of the human resources (HR), which has a competitive and comparative advantage. Efforts to prepare human resources who excel one of which can be achieved through education. Writing is also motivated by the problems associated with the low quality of education on a national scale, one of which was attributed to the weak capability of teachers in carrying out professional duties. Challenges and demands on the professionalism of teachers in the future will be more severe with the rapid development of society, science and technology as well as competition in the era of globalization. To ensure improvement of the quality of education in the future, the necessary efforts to optimize the process of coaching and primary school teachers' professional development through education and continuous training and comprehensive with greater access and reach all teachers nationwide.

Keywords: problems of education, teachers' professionalism, the new paradigm, the primary school. 


\section{Didaktik : J urnal Pendidikan Guru Sekolah Dasar, ISSN : 2477-5673 \\ Sekolah Tinggi Keguruan dan Ilmu Pendidikan Subang \\ Volume I Nomor 1, Desember 2015}

\section{PENDAHULUAN}

Tujuan pendidikan merupakan hal-hal yang sangat mendasar (fundamental), karena dari tujuan itulah akan menentukan kearah mana anak didik akan dibawa. Pendidikan merupakan suatu hal yang sangat penting dan tidak dapat dipisahkan dalam kehidupan manusia, baik dalam kehidupan keluarga, maupun dalam kehidupan berbangsa dan bernegara. Maju mundurnya suatu bangsa akan ditentukan oleh maju mundurnya pendidikan dari suatu bangsa tersebut. Karena, pada hakikatnya pendidikan masih diyakini oleh banyak kalangan sebagai upaya strategis untuk melakukan perubahan, dan merupakan bentuk upaya ikhtiar dalam membentuk pribadi manusia serta mempersiapkan generasi muda untuk mengarungi bahtera kehidupan yang lebih baik dimasa yang akan datang. Sementara itu, guru memiliki peranan penting dalam dunia pendidikan. Dimana guru harus dapat memberikan informasi pengetahuan yang optimal kepada siswa. Memberikan pengetahuan pada siswa bukanlah hal yang mudah untuk dilakukan guru mengingat beragam pola tingkah laku yang dimiliki siswa di dalam kelas, membuat guru harus mengatasi berbagai macam hal yang terjadi di kelas.

Menurut UU No. 14 tahun 2005 Guru adalah pendidik profesional dengan tugas utama mendidik, mengajar, membimbing, mengarahkan, melatih, menilai, dan mengevaluasi peserta didik pada pendidikan anak usia dini jalur pendidikan formal, pendidikan dasar, dan pendidikan menengah. Guru adalah orang yang memiliki kemampuan merancang program pembelajaran serta mampu menata dan mengelola kelas agar peserta didik dapat belajar dan pada akhirnya dapat mencapai tingkat kedewasaan sebagai tujuan akhir dari proses pendidikan. Jadi, guru adalah orang dewasa yang secara sadar bertanggung jawab dalam mendidik, mengajar, dan membimbing peserta didik. Kualitas guru Indonesia pada saat ini disinyalir sangat memprihatinkan. Berdasarkan data Posmetro Padang dari Kementerian Pendayagunaan Aparatur Negara dan Reformasi Birokrasi (Kemen PAN-RB) mencatat, hingga akhir 2013 jumlah guru yang belum Sarjana atau D-IV mencapai 1.034 .080 orang. Realitas semacam ini, pada akhirnya akan mempengaruhi kualitas anak didik yang dihasilkan menjadi tidak optimal.

Berbagai masalah tentang guru beredar di masyarakat kita bahwa profesi sebagai pendidik adalah profesi yang tidak menjanjikan dan bahkan berposisi sebagai profesi yang nomor sekian di bawah profesi-profesi lain. Bahkan hal itu sudah menjadi konvensi yang mengakar dalam pola pikir masyarakat kita. Akibatnya, banyak orang yang menjadikan profesi guru sebagai profesi loncatan atau sebagai terminal terakhir setelah mencapai kegagalan dalam mencari profesi lain. Kalau sudah begini, apakah mungkin dunia pendidikan akan melahirkan manusia-manusia berkualitas dan bermoral serta peradaban yang bisa membangun negeri ini menuju ke puncak kejayaannya, sedangkan para pendidiknya berangkat dari unsur keterpaksaan dan tidak berasal dari hati nuraninya untuk menjadi pendidik? Bagaimana mungkin pendidik bisa mengajarkan sesuatu yang benar secara nurani dan 


\section{Didaktik : J urnal Pendidikan Guru Sekolah Dasar, ISSN : 2477-5673 Sekolah Tinggi Keguruan dan IImu Pendidikan Subang Volume I Nomor 1, Desember 2015}

bermoral dari segi perilaku, sedangkan pola dan paradigma kehidupannya sudah tidak berangkat dari jalur yang benar?

Dari berbagai pernyataan tersebut, tentulah bisa diprediksi bagaimana guru karbitan tersebut mendidik anak didiknya. Profesionalisme profesi guru pun menjadi tidak ada artinya dan hanya menjadi semboyan belaka, sebab cara mendidiknya tentu saja tidak profesional dan tidak mengerti cara mendidik yang benar dan tepat sehingga bisa melahirkan generasi penerus yang mumpuni dan berpendidikan secara holistik. Karena tentu saja guru karbitan tidak akan mengerti bagaimana cara mendidik yang baik, bagaimana cara mengajarkan suatu pelajaran, bagaimana cara menguasai kelas dengan baik, serta bagaimana memberikan suatu pelajaran secara efektif dan efisien sesuai dengan standar-standar pengajaran dengan berbagai metode dan strategi pengajarannya. Bahkan, jangankan guru karbitan, guru yang sudah bergerak dari jalur guru sejak awalnya pun belum tentu bisa menguasai berbagai metode dan strategi pengajaran dengan baik dalam proses pembelajaran di kelas.

Profesi sebagai guru memiliki peran yang sangat strategis dalam proses pencerdasan, pembudayaan, dan pembangunan karakter bangsa. Pencanangan guru sebagai jabatan profesi pada tahun 2004 merupakan kebijakan strategis nasional untuk menjadikan jabatan guru sebagai jabatan profesi dan menjadi modal dasar dalam meningkatkan mutu pendidikan nasional secara komprehensif. Dengan tugas-tugas seperti yang tertera dalam UU Nomor 14 Tahun 2005, guru menjadi faktor kunci dan "the front liner" dalam upaya peningkatan kualitas sumber daya manusia dan peningkatan mutu pendidikan di tingkat satuan pendidikan. Sebagai konsekuensinya, guru harus memiliki kemampuan yang memadai dan terstandar untuk memecahkan masalah-masalah pendidikan dan mewujudkan proses pembelajaran yang berkualitas.

Kapabilitas guru pada semua jenjang pendidikan, terutama guru sekolah dasar (SD), sering mendapatkan sorotan yang mengarah pada ketidakpuasan dan ketidakpercayaan dari sebagian anggota masyarakat. Penyebabnya bisa berasal faktor guru itu sendiri maupun dari prestasi belajar yang dicapai oleh siswa. Berdasarkan beberapa hasil kajian, masih terdapat kelemahan dan kendala yang berkaitan langsung dengan mutu guru SD yang jika tidak segera diatasi akan berdampak pada rendahnya kualitas pendidikan di masa mendatang.

Permasalahan yang terkait dengan kualiatas guru menuntut adanya reformasi guru yang ditandai adanya perubahan "mind sef" tentang guru sebagai pihak yang berada di garis depan pencapaian tujuan pendidikan nasional. Salah satu aspek strategis yang menjadi fokus perubahan dalam reformasi guru yaitu berkaitan dengan peningkatan kualifikasi akademik dan kompetensi guru. Kualifikasi akademik merupakan salah satu prasyarat utama yang menentukan kelayakan seorang guru dalam melaksanakan tugas kependidikan. Pada kenyataannya masih terdapat sekitar $74 \%$ guru SD yang belum memiliki kelayakan kualifikasi akademik (S-1) sehingga harus ditingkatkan kualifikasi akademiknya. 


\section{Didaktik : J urnal Pendidikan Guru Sekolah Dasar, ISSN : 2477-5673 \\ Sekolah Tinggi Keguruan dan IImu Pendidikan Subang \\ Volume I Nomor 1, Desember 2015}

Mutu dan profesionalitas guru sangat dipengaruhi oleh aspek pendidikan dan/atau pelatihan lanjutan yang dialaminya pada saat memangku jabatan sebagai guru (in-service teacher training). Permasalahan yang sering muncul dalam pelaksanaan pendidikan/pelatihan guru dalam jabatan, diantaranya : (a) materi penataran yang diberikan bukan yang dibutuhkan oleh guru, (b) penatar sering tidak lebih bermutu pengetahuannya dan juga tidak lebih lama pengalamannya dari yang ditatar, (c) kegiatan penataran biasanya diselenggarakan pada jam efektif dimana para guru seharusnya mengajar, (d) penataran dipandang guru hanya sebagai paksaan untuk memperoleh sertifikat, dan (e) penyelenggaraan pelatihan pada umumnya sangat berorientasi pada proyek. Permasalahan-permasalahan tersebut akan berakibat terhadap rendahnya kualitas kinerja guru yang pada akhirnya akan sangat berpengaruh juga terhadap perolehan hasil belajar siswa yang diajarnya.

\section{LANDASAN TEORI}

\section{PAYUNG HUKUM GURU SEBAGAI PROFESI}

Selama proses mengajar, profesionalitas guru dijalankan dengan prinsip-prinsip tertentu. Guru perlu mengetahui dan dapat menerapkan beberapa prinsip mengajar agar ia dapat melaksanakan tugasnya secara profesional (Hamzah B. Uno, 2010:16), yaitu sebagai berikut: (1) Guru harus dapat membangkitkan perhatian peserta didik pada materi pelajaran yang diberikan serta dapat menggunakan berbagai media dan sumber belajar yang bervariasi. (2) Guru harus dapat membangkitkan minat peserta didik untuk aktif dalam berpikir serta mencari dan menemukan pengetahuan sendiri. (3) Guru harus dapat membuat urutan (sequence) dalam pemberian pelajaran dan penyesuaiannya dengan usia dan tahapan tugas perkembangan peserta didik. (4) Guru perlu menghubungkan pelajaran yang akan diberikan dengan pengetahuan yang telah dimiliki peserta didik, agar peserta didik menjadi mudah dalam memahami pelajaran yang diterimanya. (5) Sesuai dengan prinsip repetisi dalam proses pembelajaran, diharapkan guru dapat menjelaskan unit pelajaran secara berulang-ulang hingga tanggapan peserta didik menjadi jelas. (6) Guru wajib memperhatikan korelasi antara mata pelajaran dengan praktik nyata dalam kehidupan sehari-hari. (7) Guru harus tetap menjaga konsentrasi belajar para peserta didik dengan cara memberikan kesempatan berupa pengalaman secara langsung, mengamati/meneliti, dan menyimpulkan pengetahuan yang didapatnya. (8) Guru harus mengembangkan sikap peserta didik dalam membina hubungan sosial, baik dalam kelas maupun di luar kelas. (9) Guru harus menyelidiki dan mendalami perbedaan peserta didik secra individual agar dapat melayani siswa sesuai dengan perbedaannya tersebut.

Berdasarkan uraian diatas, dapat diambil kesimpulan mengenai hakikat profesi dan pengakuan profesi kependidikan. Profesi merupakan janji terbuka yang diucapkan dengan sungguh-sungguh di hadapan orang lain, Tuhan, diri sendiri karena idealisme seseorang untuk mengabdi seumur hidup demi mencapai kemaslahatan manusia. Kemudian, jabatan guru telah mendapatkan pengakuan secara yuridis melalui UU 


\section{Didaktik : J urnal Pendidikan Guru Sekolah Dasar, ISSN : 2477-5673 \\ Sekolah Tinggi Keguruan dan Ilmu Pendidikan Subang \\ Volume I Nomor 1, Des ember 2015}

No. 20 tahun 2003, UU No 14 Tahun 2005, dan peraturan perundangundangan lainnya. Oleh karena itu, profesi guru harus mendapatkan tempat yang istimewa dibandingkan dengan pekerjaan lainnya yang bukan pekerjaan profesi.

Terkait dengan kompetensi pendidik, dapat dijelaskan masing-masing kompetensi sebagai berikut: (a) Kompetensi Pedagogik. Guru memiliki pemahaman yang mendalam tentang ilmu pendidikan, landasan kepribadian, karakteristik peserta didik, bimbingan dan konseling, administrasi pendidikan, kurikulum dan evaluasi pendidikan, metode mengajar serta keterampilan mengajar (keterampilan bertanya, menjawab pertanyaan, membuka dan menutup pelajaran).

Kompetensi

Profesional. Guru memiliki pemahaman yang komprehensif tentang bidang studi yang diajarkannya, dan memiliki komitmen untuk senantiasa meningkatkan kualitas keilmuannya, baik dengan mengikuti pendidikan lebih lanjut, seminar-seminar maupun pelatihanpelatihan.(c) Kompetensi Sosial. Guru memilki kemampuan untuk berinteraksi sosial secara positif dengan orang lain, baik sesama guru, pimpinan sekolah, orang tua peserta didik, peserta didik dan pihak lain. (d) Kompetensi Kepribadian. Guru memilki karakteristik kepribadian yang mantap atau akhlak mulia, sebagai suri tauladan, atau figur moral bagi peserta didik. Karakteristik pribadi guru diantaranya adalah; ikhlas, sabar, jujur, rendah hati, disiplin, istiqomah, bersikap respek, antusias, memiliki motif, mencintai, bersikap ramah, lemah lembut, bersikap adil, bertutur kata yang sopan, berpenampilan sederhana, mau bekerja sama dengan orang lain, bersikap percaya diri.

\section{HUBUNGAN PROFESIONALISME DAN GURU}

Sehubungan dengan perlunya humanware dalam pendidikan di sekolah, lahirnya Undang-undang Republik Indonesia No. 14 Tahun 2005 tentang Guru dan Dosen pada pasal 8, yang menyebutkan bahwa "Guru wajib memiliki kualifikasi akademik, kompetensi, sertifikasi pendidik, sehat jasmani dan rohani serta memiliki kemampuan untuk mewujudkan tujuan pendidikan nasional', telah mengisyaratkan bahwa adanya tuntutan bagi guru di seluruh jenjang pendidikan untuk memiliki kualifikasi akademik yang sesuai dengan pekerjaannya.

Landasan hukum tersebut, secara otomatis telah mendesak berbagai perguruan tinggi untuk mendirikan dan menyelenggarakan program Pendidikan Guru Sekolah Dasar (PGSD). Hal ini disebabkan karena terdapatnya sebagian besar guru pada Sekolah Dasar (SD) di daerah Indonesia yang belum mengenyam pendidikan Strata Satu (S1). Dengan terselenggaranya PGSD, diharapkan dapat meningkatkan kualitas dan profesionalitas guru di sekolah. Tentu saja dengan suatu pertimbangan guru dalam pendidikan memainkan peranan yang vital bagi terciptanya pendidikan yang bermutu dan membentuk peserta didik yang cerdas, berkarakter, bermoral dan berkepribadian atau dalam bahasa UNESCO (1996) seorang guru mampu moulding the character and mind of young generation. Dikatakan vital, sebab guru merupakan tenaga profesional yang bertugas merencanakan dan melaksanakan 


\section{Didaktik : J urnal Pendidikan Guru Sekolah Dasar, ISSN : 2477-5673 \\ Sekolah Tinggi Keguruan dan Ilmu Pendidikan Subang \\ Volume I Nomor 1, Des ember 2015}

proses pembelajaran, menilai hasil pembelajaran, melakukan bimbingan dan pelatihan, serta melakukan penelitian dan pengabdian kepada masyarakat. Ibarat sebuah mata rantai, antara guru, peserta didik, tujuan pendidikan, alat dan situasi pendidikan semua terikat secara sinergik dalam membangun kualitas pendidikan secara totalitas. Akan tetapi, karena pendidikan dilakukan oleh dan kepada manusia, maka faktor manusia dalam hal ini guru menempati posisi sentral dalam pendidikan.

Guru adalah pihak yang bertanggung jawab terhadap pelaksanaan pendidikan dan pengajaran, guru memegang peranan yang strategis dalam inovasi pelaksanaan dan pengajaran di sekolah. Di kelas, guru adalah key person (pribadi kunci) yang memimpin dan mengarahkan kegiatan belajar mengajar para siswanya. Di mata siswa, guru adalah seorang yang mempunyai otoritas bukan saja dalam bidang akademis dan juga non akademis. Bahkan dalam masyarakat, guru dipandang sebagai orang yang harus di guguh dan ditiru. Oleh sebab itulah, berdirinya PGSD bisa dikatakan sebagai upaya untuk dapat membawa perubahan dalam sistem pendidikan di sekolah, dan melahirkan SDM yang handal serta tercapainya tujuan yang diharapkan adanya tipologi guru yang memiliki karakteristik tertentu, yang pada masa sekarang disebut guru yang berkompetensi. Guru yang berkompetensi menggambarkan bahwa guru harus memiliki/menampilkan sosok kualitas personal (kepribadian), profesional dan sosial dalam menjalankan tugasnya.
Seseorang yang dikatakan profesional, menurut Muhaimin dalam Syamsul Ma'arif (2009), “Bilamana pada dirinya melekat sikap dedikatif yang tinggi terhadap tugasnya, sikap komitmen terhadap mutu proses dan hasil kerja, serta sikap continous improvement, yakni selalu berusaha memperbaiki dan memperbaharui model-model atau cara kerjanya sesuai dengan tuntunan zamannya, yang dilandasi oleh kesadaran yang tinggi bahwa tugas mendidik adalah tugas menyiapkan generasi penerus yang akan hidup pada zamannya di masa depan". Sosok guru ideal yang diharapkan pendidikan sekarang adalah seorang ilmuwan dengan ciriciri sebagai berikut; (1) Peka terhadap masalah, Karena kepekaan seperti ini merupakan penggerak kreatifitas. Bagi ilmuwan yang lebih penting adalah memikirkan pertanyaan untuk suatu jawaban daripada menjawab pertanyaan yang sudah ada. (2) Bekerja tanpa pamrih, Dalam dunia ilmu sikap tanpa pamrih biasanya diberi makna obyektif, cinta kebenaran dan kritis. Tetapi bukan obyektif yang dingin, cinta kebenaran yang impersonal atau sekedar membuka diri untuk selalu kritis dan bersedia menerima kritik. Melainkan, sifat tanpa pamrih mendorong ilmuwan untuk tidak semata mengindahkan kepentingan sendiri, sebaliknya harus membuka diri untuk setiap kebenaran termasuk yang tidak berasal dari dirinya, bahkan bersedia mempertaruhkan diri walaupun dengan itu seolah hakekat kemanusiaannya menjadi semu belaka. (3) Bersikap bijaksana, kebijakan mengandung makna adanya hubungan timbal balik antara pengenalan dan tindakan, antara pengertian praktis etis yang sesuai. (4) Tanggung jawab, seorang ilmuwan berkewajiban mencari, menemukan 


\section{Didaktik : J urnal Pendidikan Guru Sekolah Dasar, ISSN : 2477-5673 \\ Sekolah Tinggi Keguruan dan IImu Pendidikan Subang \\ Volume I Nomor 1, Des ember 2015}

dan memanfaatkan ilmu bagi keperluan hidup umat manusia, sekaligus juga harus bertanggung jawab atas apa yang terjadi selanjutnya jika dengan ilmu itu ternyata menimbulkan kerusakan lingkungan di alam ini, lalu berusahalah ia untuk mencari lagi jalan keluarnya. Dengan begitu, jelaslah bahwa sosok guru dengan karakter "Cerdas, Kreatif, dan Beradab" adalah sosok yang sangat dibutuhkan pendidikan dasar di Indonesia untuk menghadapi zaman globalisasi, yaitu sosok yang diharapkan dengan memiliki berbagai macam kecerdasan di dalam dirinya, baik itu kecerdasan fisik, kecerdasan intelektual, kecerdasan sosial, kecerdasan emosional, dan kecerdasan spritual.

\section{PARADIGMA PENDIDIKAN BARU}

Dalam menentukan tujuan pendidikan ada beberapa nilai yang perlu diperhatikan, seperti yang dikemukakan oleh Hummel dalam Sadulloh (2011: 73) antara lain: (1) Autonomy. Gives individuals and groups the maximum awareness, knowledge and ability so that they can manage their personal and collective life to the greates possible extent. (2) Equity. Enable all citizens to participate in cultural and economic life by coffering them an equal basic education. (3) Survival. Permit every nation to transmit and enrich its cultural heritage over the generations, but also guide education towards mutual understanding and towards what has become a worldwide realizations of common destiny. Tujuan pendidikan harus mengandung nilai tersebut. Pertama, Autonomy, yaitu memberi kesadaran, pengetahuan, dan kemampuan secara maksimum kepada individu maupun kelompok, untuk dapat hidup mandiri, dan hidup bersama dalam kehidupan yang lebih baik. Kedua, Aquity (keadilan), berarti bahwa tujuan pendidikan tersebut harus memberi kesempatan kepada seluruh warga masyarakat untuk dapat berpartisipasi dalam kehidupan berbudaya dan kehidupan ekonomi dengan memberinya pendidikan dasar yang sama. Ketiga, Survival, yang berarti bahwa dengan pendidikan akan menjamin pewarisan kebudayaan dari satu generasi kepada generasi berikutnya. Berdasarkan ketiga nilai tersebut, pendidikan mengemban tugas untuk menghasilkan generasi yang lebih baik, manusia-manusia yang berkebudayaan. Manusia sebagai individu yang memiliki kepribadian yang lebih baik. Nilai-nilai di atas menggambarkan pendidikan dalam suatu konteks yang sangat luas, menyangkut kehidupan seluruh umat manusia, dimana digambarkan bahwa tujuan pendidikan adalah untuk menciptakan suatu kehidupan yang lebih baik. Pancasila sebagai pandangan hidup bangsa merupakan dasar dan sekaligus tujuan yang ingin dicapai dalam melaksanakan pendidikan. Kegiatan pendidikan ditujukan untuk menghasilkan manusia seutuhnya, manusia yang memiliki kepribadian yang lebih baik, yaitu manusia di mana sikap dan prilakunya dalam kehidupan bermasyarakat dan bernegara dijiwai oleh nilai-nilai Pancasila. Manusia seutuhnya, manusia yang menghayati dan sekaligus mampu mengamalkan Pancasila.

Munculnya berbagai perubahan yang sangat cepat hampir di semua lini kehidupan, dan telah menggeser paradigma lama menjadi paradigma baru. Seiring dengan itu pula, pendidikan mencoba merespon setiap 


\section{Didaktik : J urnal Pendidikan Guru Sekolah Dasar, ISSN : 2477-5673 Sekolah Tinggi Keguruan dan IImu Pendidikan Subang Volume I Nomor 1, Desember 2015}

perubahan yang terjadi. Dengan maksud, agar kualitas yang dihasilkan pendidikan tidak lagi dinilai kadaluwarsa dan tidak peka terhadap perkembangan zaman. Dengan itu pendidikan melakukan perubahanperubahan di beberapa hal diantaranya telah dikembangkannya kurikulum baru dan dikembangkannya berbagai metode dan model pendidikan terbaru. Kurikulum dan model maupun metode tersebut berbeda jauh dari metode dan model lama. Model dan metode baru ini lebih menekankan pada peran dan aktivitas peserta didik ketimbang dominasi guru di dalam kelas. Disamping itu model dan metode baru ini lebih membawa peserta didik pada kenyataan yang ada disekelilingnya, ketimbang menjejali mereka dengan teori-teori yang "mengawang".

Semua materi yang di ajarkan di sekolah merupakan salah satu mata pelajaran yang harus mengikuti standar kurikulum baru tersebut. Dalam rangka mencapai standar isi, artinya bahwa materi yang diajarkan diarahkan untuk menyiapkan peserta didik untuk mengenal, memahami, dan menghayati peristiwa yang ada dalam kehidupan yang kemudian bisa menjadi inspirasi bagus dasar pandangan hidupnya (way of life) melalui kegiatan bimbingan, pengajaran, latihan, penggunaan pengalaman, pembiasaan, dan keteladanan. Namun ada satu hal yang sangat mendasar terkait dengan pengajaran materi di sekolah dasar ini, adalah kemampuan guru dalam menggali nilai, makna, aksioma, hikmah, dalil, dan teori dari fakta-fakta yang ada. Materi yang disampaikan guru hendaknya tidak berhenti pada transfer of knowledge, tetapi juga merupakan pendidikan nilai (value).
Kondisi terpuruknya pendidikan di Indonesia dibanding negara-negara lain tersebut, tentunya menjadi dorongan sekaligus tantangan khususnya bagi guru untuk selalu membenahi diri dan meningkatkan kompetensinya agar mampu meningkatkan sumber daya manusia sekaligus menanamkan nilai-nilai ajaran agama secara efektif kepada peserta didiknya. Selain itu, para guru harus menyadari bahwa salah satu penyebab kegagalan pendidikan di Indonesia selama ini adalah masih mengembangkan model doktrinisasi dogmatikal, bukan pendidikan yang komunikatif transformatif. Maka materi-materi pendidikan, biasanya hanya singgah di kepala peserta didik sebentar menjelang saat ujian dan setelah itu "terlupakan", tidak pernah masuk ke hati dan tidak pernah dilaksanakan dalam kehidupan seharihari. Semua yang dipelajari di sekolah tidak dilakukan dalam kerangka mengembangkan pribadi dan menghayati kehidupan yang bersih lahir dan batin, tetapi hanya sekedar untuk memenuhi tuntutan ritual formal. Disinilah letak pentingnya para guru untuk mengajarkan materi yang lebih "bermakna" dengan penekanan pendidikan yang seimbang, tidak hanya didominasi kecerdasan intelektual semata, melainkan juga melibatkan emosi. Konsep pembelajaran aktif tersebut tentu saja berbeda dengan konsep pembelajaran yang selama ini terjadi. Karena dengan Active Learning, proses pembelajaran berpindah dari situasi "teacher dominated learning" ke situasi "student dominated learning". Siswa disini lebih dipandang sebagai manusia dengan segala potensi yang dimilikinya. Guru hanya sebagai fasilitator sekaligus teman dalam mencari ilmu pengetahuan. Karena posisi siswa sebagai subyek dan aktor 
dalam proses belajar mengajar, maka kemungkinan siswa lebih aktif dan kreatif dalam proses pembelajaran.

\section{KESIMPULAN}

Upaya menyiapkan sumber daya manusia yang unggul salah satunya dapat dicapai melalui pendidikan sekolah dasar (SD). Pendidikan yang bermutu akan didukung oleh guruguru yang memegang prinsip-prinsip profesionalisme guru. Profesionalitas guru dijalankan dengan prinsip-prinsip tertentu agar dapat melaksanakan tugas-tugasnya secara profesional. Sosok guru dengan karakter "Cerdas, Kreatif, dan Beradab" adalah sosok yang sangat dibutuhkan pendidikan dasar di Indonesia untuk menghadapi zaman globalisasi, yaitu sosok yang diharapkan dengan memiliki berbagai macam kecerdasan di dalam dirinya, baik itu kecerdasan fisik, kecerdasan intelektual, kecerdasan sosial, kecerdasan emosional, dan kecerdasan spritual.

\section{DAFTAR PUSTAKA}

Ma'arif, Syamsul. (2009). Selamatkan Pendidikan Dasar Kita. Semarang: Need's Press

Sadulloh, Uyoh. (2011). Pedagogik (Ilmu Mendidik). Bandung:

Alfabeta

Uno, Hamzah. (2010). Profesi Kependidikan. Jakarta: Bumi Aksara

http://posmetropadang.com/index.php ?option=com_content\&task=view\& id $=8643 \&$ Itemid $=27$ 